\title{
Characteristics of farmers' selection criteria for cowpea (Vigna unguiculata) varieties differ between north and south regions of Burkina Faso
}

\author{
Haruki Ishikawa $^{1, \star(D)}$, Issa Drabo², Batieno B. Joseph², Satoru Muranaka ${ }^{3}$, Christian Fatokun ${ }^{1}$ and \\ Ousmane Boukar ${ }^{1}$

\begin{abstract}
${ }^{1}$ International Institute of Tropical Agriculture (IITA), PMB 5320, Oyo Road, Ibadan 200001, Oyo State, Nigeria, ${ }^{2}$ Institut de l'Environnement et de Recherches Agricoles (INERA), 04 BP 8645 Ouagadougou 04, Burkina Faso and ${ }^{3}$ Japan International Research Center for Agricultural Sciences (JIRCAS), 1-1, Ohwashi, Tsukuba, Ibaraki 305-8686, Japan
\end{abstract} \\ *Correspondence. Email: h.ishikawa@cgiar.org
}

(Received 11 October 2018; revised 01 March 2019; accepted 27 May 2019; first published online 18 July 2019)

\begin{abstract}
Summary
Comparative analysis of preferences and key criteria for selecting cowpea (Vigna unguiculata L. Walp.) varieties was conducted using the data collected from farmers' participatory varietal selection (FPVS) activities conducted over 3 years with a total of 2401 farmers ( 1230 male and 1171 female) in 13 villages in Tougouri department in northern region and Tiéfora department in southern region of Burkina Faso in West Africa. Over the 3 years, farmer criteria for variety selection remained basically stable, but some variations among the regions and years were noticed. Grain yield was the most common and the most important criterion for farmers' choice in both regions. Farmers in Tougouri (north) put more emphasis on early maturity (90\%) and drought resistance (19.7\%) as selection criteria than farmers in Tiéfora (south). Farmers in Tiéfora placed statistically significant importance on seed colour and plant type, while farmers in Tougouri did not, and for these selection criteria, there were only slight differences between genders in both areas. Results of stepwise multiple regression indicated that maturity and seed colour in the north, and seed size and seed colour in the south were the most important selection factors for farmers to select cowpea varieties. Improved varieties should have sufficiently good yield to be accepted, but other favoured traits may differ by target region as a reflection of local and regional market demands as well as deep-rooted cultural preferences. Understanding local and regional differences in selection criteria for cowpea varieties is necessary to improve the acceptance of newly released improved varieties. Preferences identified in the participatory activities could inform further development of cowpea breeding strategies for north and south regions of Burkina Faso.
\end{abstract}

Keywords: Cowpea; Burkina Faso; Farmers criteria; Participatory varietal selection; Regional difference

\section{Introduction}

Cowpea (Vigna unguiculata L. Walp.) is an important crop for promoting food security, and it provides a primary source of protein in diets that lack animal proteins due to inaccessibility, poverty or dietary preferences (Muranaka et al., 2015). As it is well adapted to the dry savannah climate of West Africa, cowpea provides a livelihood and income for farmers, particularly in sub-Saharan Africa where it is grown as a cash crop in Burkina Faso, Ghana, Nigeria, Mali, Mauritania, Niger and Senegal (Mortimore et al., 1997; Kormawa et al., 2002). 
International and national cowpea breeding programmes have developed and released various improved varieties for sub-Saharan African countries. Although these varieties have higher yield and are more resistant to biotic and abiotic stresses, reports on farmers' selection criteria and acceptance of improved cowpea varieties remain limited (Kitch et al., 1998; LowenbergDeBoer, 1994; Sanders et al., 1994). Reports of farmer participation in cowpea improvement efforts are few and are primarily restricted to descriptions of on-farm trials in annual reports of the National Agricultural Research Systems (Kitch et al., 1998). However, discrepancies exist between farmers' preferences and the availability of improved cowpea varieties in northern Nigeria, emphasising the importance of improving researchers' understanding based on a wide range of criteria and local preferences in the production and utilisation of cowpea (Kamara et al., 2009). Furthermore, the acceptance of varieties by farmers varies by region and depends on environmental conditions, competing demands for food and cash, accessibility to markets and cultural preferences. Multiple regression analysis and/or hedonic pricing methods are also utilised to identify the cowpea traits/preferences (Faye et al., 2006; Langyintuo et al., 2004; Mishili et al., 2007). As farmers are both producers and consumers of cowpea in many cases, a better understanding of farmers' selection criteria in the target region is critical to improving the acceptance rate of newly developed cowpea varieties, and can contribute to the enhancement for the cowpea market value chain.

A small farmer dealing with variable environmental and socioeconomic conditions considers multiple production objectives when selecting a cowpea variety to grow. Farmers' participatory varietal selection (FPVS) is a rapid and cost-effective way to identify farmer-preferred cultivars in the case that there is a suitable variety of choices (Witcombe et al., 1996). Participatory evaluation improves farmers' understanding of the benefits of the introduced varieties, which in turn promotes their adoption and also provides important feedback about the performance of the varieties under local cropping systems to cowpea breeders (Ashby and Lija, 2005; Sperling et al., 1993). Burkina Faso is the third largest producer of cowpea in the world (FAOSTAT, 2014) and a major exporter of cowpea to West African countries, such as Nigeria, Mali, Ghana and Cote d'Ivoire. However, based on the breeders' understanding, it is suggested that the farmers' preference for their cowpea varieties is not always aligned with market preferences as reported by Mishili et al. (2007), and it is assumed that those preferences are quite different between north and south regions. In addition, it is expected that the farmers' acceptability often extend to the multiple traits, such as seed colour, texture, and size (Langyintuo et al., 2003, 2004). Therefore, the final decision of farmer's varietal selection is based on a combination of two or more traits/preferences combination, which depends on the specific region and/or sex. There is no evidence-based information on the actual preference of the farmers for their selection of cowpea variety, though it is important information that affects the acceptability of an introduced variety.

In this study, a comparative analysis of farmers' activities was performed taking into account the FPVS programmes undertaken in major cowpea producing areas of regions in the north and south of Burkina Faso. The objectives of this study were to identify the key traits/preferences of farmers' for cowpea among different regions and according to sex. Finally, this study aims to provide information to cowpea breeders in order to promote effective breeding activities to develop more widely accepted cowpea varieties in these specific regions.

\section{Materials and Methods}

\section{Plant materials and target villages}

FPVS practices were evaluated by survey conducted during 2014-2016 in 13 villages, eight in the north region of Centre-Nord (Namentenga Province, Tougouri Department) and five in the south region of Cascades (Comoe Province, Tiéfora Department) of Burkina Faso (Table 1). Ten varieties were selected to represent various combinations of characteristics, such as maturity, plant type, Striga gesnerioides resistance, seed colour, seed size and seed coat texture. Demonstration 
Table 1. Locations of villages in Burkina Faso where FPVS activities were conducted

\begin{tabular}{|c|c|c|c|c|c|c|c|c|}
\hline Region & Province & Department & Village & Latitude & Longitude & Effective rainfall* & Total participants ${ }^{\star \star}$ & $\begin{array}{l}\text { Cowpea farmer per } \\
\text { households }(\%)^{\star \star \star}\end{array}$ \\
\hline \multirow[t]{8}{*}{ Centre-Nord (North) } & Namentenga & Tougouri & Nioundougou & $13^{\circ} 10^{\prime} 7.42^{\prime \prime} \mathrm{N}$ & $0^{\circ} 27^{\prime} 49.35^{\prime \prime} \mathrm{W}$ & $543.0-645.5$ & 234 (M:111,F:123) & 92.4 \\
\hline & & & Ouatinapam & $13^{\circ} 5^{\prime} 30.35^{\prime \prime} \mathrm{N}$ & $0^{\circ} 26^{\prime} 37.33^{\prime \prime} \mathrm{W}$ & $543.0-645.5$ & 182 (M:77, F:105) & 97.1 \\
\hline & & & Kalitaguin & $13^{\circ} 7^{\prime} 50.72 " \mathrm{~N}$ & $0^{\circ} 32^{\prime} 47.02^{\prime \prime} \mathrm{W}$ & $543.0-645.5$ & 192 (M:107, F:85) & 100 \\
\hline & & & Tidimtoa & $13^{\circ} 8^{\prime} 43.09^{\prime \prime} \mathrm{N}$ & $0^{\circ} 21^{\prime} 44.90^{\prime \prime} \mathrm{W}$ & $543.0-645.5$ & 196 (M:106, F:90) & 87.4 \\
\hline & & & Satambila & $13^{\circ} 15^{\prime} 37.16^{\prime \prime} \mathrm{N}$ & $0^{\circ} 22^{\prime} 32.08^{\prime \prime} \mathrm{W}$ & $543.0-645.5$ & 238 (M:89, F:149) & 100 \\
\hline & & & Sagouem & $13^{\circ} 21^{\prime} 31.47^{\prime \prime} \mathrm{N}$ & $0^{\circ} 26^{\prime} 56.36^{\prime \prime} \mathrm{W}$ & $543.0-645.5$ & 174 (M:74, F:100) & 100 \\
\hline & & & Daouirba & $13^{\circ} 7^{\prime} 43.82^{\prime \prime} \mathrm{N}$ & $0^{\circ} 38^{\prime} 11.11^{\prime \prime} \mathrm{W}$ & $543.0-645.5$ & 215 (M:115, F:100) & 100 \\
\hline & & & Dabossomnoré & $13^{\circ} 8^{\prime} 18.01^{\prime \prime N}$ & $0^{\circ} 28^{\prime} 47.88^{\prime \prime} \mathrm{W}$ & $543.0-645.5$ & 136 (M:69, F:67) & 100 \\
\hline \multirow[t]{5}{*}{ Cascades (South) } & Comoe & Tiéfora & Sankara & $10^{\circ} 25^{\prime} 66.03^{\prime \prime} \mathrm{N}$ & $4^{\circ} 34^{\prime} 65.07^{\prime \prime} \mathrm{W}$ & $815.9-964.5$ & 176 (M:114, F:62) & 90.3 \\
\hline & & & Bamako & $10^{\circ} 32^{\prime} 51.12^{\prime \prime} \mathrm{N}$ & $4^{\circ} 34^{\prime} 32.65^{\prime \prime} \mathrm{W}$ & $815.9-964.5$ & 197 (M:117, F:80) & 94.6 \\
\hline & & & Boussara 1 & $10^{\circ} 31^{\prime} 28.52^{\prime \prime} \mathrm{N}$ & $4^{\circ} 34^{\prime} 47.24^{\prime \prime} \mathrm{W}$ & $815.9-964.5$ & 199 (M:90, F:109) & 78.8 \\
\hline & & & Labo la Kassianra & $10^{\circ} 35^{\prime} 50.82^{\prime \prime} \mathrm{N}$ & $4^{\circ} 37^{\prime} 33.15^{\prime \prime} \mathrm{W}$ & $815.9-964.5$ & 185 (M:111, F:74) & 91.3 \\
\hline & & & Sikane & $10^{\circ} 33^{\prime} 42.03^{\prime \prime} \mathrm{N}$ & $4^{\circ} 22^{\prime} 68.07^{\prime \prime W}$ & $815.9-964.5$ & 77 (M:51, F:26) & 93.9 \\
\hline
\end{tabular}

* Observed values from June to October at local agriculture office in Tougouri and Tiéfora in 2014-2016.

** M: number of male, F: number of female.

${ }^{\star \star \star}$ Based on responses to an interview survey 2013. 
fields were established in all 13 target villages prior to the FPVS trials. Planting dates of cowpea were typically the beginning of July for the north and the end of July to the beginning of August for the south. In each demonstration field, plots with all cowpea varieties were arranged in a randomised block design, each with three replicates $(3.2 \times 3.2 \mathrm{~m}$ per plot $)$. The cowpeas were sown with $40 \mathrm{~cm}$ between plants and $60 \mathrm{~cm}$ between rows for early maturing lines at the beginning of the rainy season in each location, fertiliser (NPK 15:15:15) was top dressed at $100 \mathrm{~kg} \mathrm{ha}^{-1}$, and 2-3 rounds of weed control and spraying for disease and insect control were carried out according to the conditions of each location. The characteristics of maturity, seed size, and seed colour were compared among varieties and sites.

\section{Participatory variety selection and questionnaire survey}

FPVS was carried out at each location once early maturing genotypes reached maturity (typically around the middle of September in the north and around the middle of October in the south). Farmers from the target and neighbouring villages were invited to the demonstration fields. Without showing the variety name on the test plots, farmers were requested to select their preferred cowpea genotypes based on plant and seed characteristics and seed samples prepared for each plot to demonstrate seed colour and size. The three most preferred cowpea varieties per plot per replication were selected. An invitation was sent to all farmers of the target and surrounding villages regardless of their social status, age, and sex, but excluded children under the age of 12 . All farmers who could attend the FPVS and questionnaire survey were treated equally.

After the field trials, local facilitators conducted a questionnaire survey in the local language and/or in French. In the survey, local facilitators recorded information obtained individually from each participant on: (i) biographical data (age, sex, education level and number of livestock owned); (ii) varieties selected (unique ID numbers) through the FPVS selection process along with the major reasons for the selection; (iii) key agronomic and grain quality traits for cowpea selection/adaptation (grain and fodder yield, maturity, plant shape, peduncle position, texture, seed colour, fodder, grain, maturity, grain size and resistance to biotic and abiotic stresses); and (iv) the farmers' current cowpea production situation (constraints, cropping system, insecticide use and fertiliser use). To obtain unprejudiced information free from social relationships, surveys were conducted on an individual basis.

\section{Statistical analysis}

Using quantity of responses (\%), the chi-squared test (test of independence) was performed to examine the significance of differences in farmers' selection/criterion among farmer-selected cowpea varieties by year, location (north or south), and the sex of the selectors. If independency was confirmed, it was shown in Tables 2, 3 and 4 as asterisks. In demonstration trials in north and south regions of Burkina Faso, field/crop parameter data, such as yield of each variety, date of $50 \%$ flowering, seed size, effective rainfall and emerged Striga number, were collected every year (Supplementary Material Table S1) and subjected to stepwise multiple regression analysis to identify the major variables influencing farmers' selection (FPVS score) in each region. The major variables influencing the dependent variable were ranked in the order of importance. The Tukey-Kramer HSD test was performed to compare yield performances. Statistical analyses were carried out in JMP 5.0.1a (SAS Institute, Cary, NC, USA).

\section{Results}

\section{Farmers' selected varieties in north and south regions of Burkina Faso}

In Tougouri department (north region), a total of 1567 farmers participated in the 3-year study with a gender-balanced composition of participants of $47.7 \%$ male to $52.3 \%$ female. The average age of participants was $34.3( \pm 3.9)$ years, and the oldest and youngest participants were 
Table 2. Cowpea varieties for FPVS activities and selection rates

\begin{tabular}{|c|c|c|c|c|c|c|c|}
\hline \multicolumn{8}{|c|}{ North } \\
\hline \multirow[b]{2}{*}{ Variety } & \multicolumn{3}{|c|}{ Selection rate } & \multirow[b]{2}{*}{ Yield (kg/ha) } & \multirow[b]{2}{*}{ Maturity } & \multirow[b]{2}{*}{ Seed size $x$} & \multirow[b]{2}{*}{ Seed colour } \\
\hline & $2014 \%$ & $2015 \%$ & $2016 \%$ & & & & \\
\hline Melakh & $56.1^{\star \star \star}$ & 24.7 & 24.2 & 900.1 & $E$ & 13.3 & White \\
\hline IT98K-205-8 & 45.5 & 47.4 & 37.4 & 854.6 & $\mathrm{EE}$ & 14.2 & White \\
\hline IT99K573-2-1 & 42.5 & 42.8 & 33.2 & 1012.6 & $\mathrm{EE}$ & 18.1 & White \\
\hline$K V x 442-3-25$ & 42.4 & 44.6 & 56.4 & 1038.3 & $E$ & 18.5 & White \\
\hline$K V \times 395-4-5-2 D$ & 27.7 & 29.6 & $46.9^{\text {** }}$ & 1204 & M & 17.1 & White \\
\hline KVx775-33-2 & 26.4 & $38.8^{*}$ & 23.8 & 973.1 & M & 19.8 & White \\
\hline KVx771-10 & 18.8 & 27.2 & $34.8^{*}$ & 938.7 & $E$ & 18.4 & White \\
\hline $\mathrm{KV} \times 61-1$ & 17.9 & 18.7 & 20.2 & 897.6 & M & 14.6 & White \\
\hline KN1 & 15.6 & 8.0 & 11.7 & 874.1 & M & 13.8 & Brown \\
\hline IT81D-994 & 7.2 & $18.2^{\star}$ & 11.3 & 706.7 & $\mathrm{~L}$ & 20.3 & White \\
\hline \multicolumn{8}{|c|}{ South } \\
\hline & \multicolumn{3}{|c|}{ Selection rate } & & & & \\
\hline Variety & $2014 \%$ & $2015 \%$ & $2016 \%$ & Yield (kg/ha) & Maturity & Seed size $\times$ & Seed colour \\
\hline$K V \times 442-3-25$ & 44.3 & 42.8 & 35.8 & 878.7 & $E$ & 17.4 & White \\
\hline Melakh & $42.0^{\star *}$ & 23.4 & 25.0 & 825.9 & $E$ & 12.5 & White \\
\hline IT81D-994 & 40.2 & 29.2 & $49.6^{\star \star}$ & 746.3 & $\mathrm{~L}$ & 18.8 & White \\
\hline $\mathrm{KN} 1$ & $35.9^{\star \star \star}$ & 13.2 & 9.8 & 714.3 & M & 13.5 & Brown \\
\hline$K V \times 395-4-5-2 D$ & 25.5 & 24.2 & $36.8^{\star \star}$ & 954.1 & M & 15.9 & White \\
\hline KVx61-1 & 24.7 & 22.9 & 26.4 & 858.6 & M & 13.9 & White \\
\hline IT99K573-2-1 & 24.2 & 33.4 & 38.0 & 760.5 & $\mathrm{EE}$ & 18.4 & White \\
\hline KVx775-33-2 & 23.5 & $35.6^{\star \star}$ & 28.0 & 910.8 & M & 18.9 & White \\
\hline IT98K-205-8 & 19.9 & 36.8 & 20.5 & 752.3 & $\mathrm{EE}$ & 13.7 & White \\
\hline KVx771-10 & 19.8 & $38.4^{\star \star}$ & 30.1 & 804.3 & $E$ & 17.5 & White \\
\hline
\end{tabular}

$\times$ Seed size (g/100 seeds) from demonstration fields in 2014-2016, E: early maturing, EE: extra-early maturing, M: medium, L: late. Asterisks indicate significant difference in selections rate across years according to chi-squared analysis,

${ }^{\star \star \star} p<0.001 ;{ }^{\star \star} p<0.01 ;{ }^{\star} p<0.05$. Hatched shading indicates top three most popular varieties of that year.

Table 3. Farmers' selection criteria for cowpea varieties by region

\begin{tabular}{rccccccccccc}
\hline & $\begin{array}{c}\text { Grain } \\
\text { yield }\end{array}$ & $\begin{array}{c}\text { Early } \\
\text { maturity }\end{array}$ & $\begin{array}{c}\text { Seed } \\
\text { size }\end{array}$ & $\begin{array}{c}\text { Plant } \\
\text { type }\end{array}$ & $\begin{array}{c}\text { Pod } \\
\text { shape }\end{array}$ & $\begin{array}{c}\text { Seed } \\
\text { colour }\end{array}$ & $\begin{array}{c}\text { Drought } \\
\text { resistance }\end{array}$ & $\begin{array}{c}\text { Disease } \\
\text { resistance }\end{array}$ & $\begin{array}{c}\text { Seed } \\
\text { texture }\end{array}$ & $\begin{array}{c}\text { Fodder } \\
\text { yield }\end{array}$ & $\begin{array}{c}\text { Striga } \\
\text { resistance }\end{array}$ \\
\hline North & 85.7 & $90.1^{\star \star *}$ & 33.2 & 10.4 & 21.1 & 19.8 & $19.7^{\star \star *}$ & 3.0 & 10.2 & 4.7 & 2.9 \\
South & 91.2 & 45.9 & 37.1 & $38.1^{\star * *}$ & 16.6 & $35.9^{\star *}$ & 6.1 & $7.6^{*}$ & 9.5 & 7.8 & 1.0 \\
\hline
\end{tabular}

Asterisks indicate a significant difference in selections rate between regions by chi-squared analysis,

${ }^{\star \star *} p<0.001 ;{ }^{\star \star} p<0.01 ;{ }^{*} p<0.05$ as shown in the manuscript.

Table 4. Famers' selection criteria for cowpea varieties by gender

\begin{tabular}{|c|c|c|c|c|c|c|c|c|c|c|c|c|}
\hline Location & Gender & $\begin{array}{l}\text { Grain } \\
\text { yield }\end{array}$ & $\begin{array}{c}\text { Early } \\
\text { maturity }\end{array}$ & $\begin{array}{l}\text { Seed } \\
\text { size }\end{array}$ & $\begin{array}{l}\text { Plant } \\
\text { type }\end{array}$ & $\begin{array}{l}\text { Pod } \\
\text { shape }\end{array}$ & $\begin{array}{l}\text { Seed } \\
\text { colour }\end{array}$ & $\begin{array}{l}\text { Drought } \\
\text { resistance }\end{array}$ & $\begin{array}{l}\text { Disease } \\
\text { resistance }\end{array}$ & $\begin{array}{l}\text { Seed } \\
\text { texture }\end{array}$ & $\begin{array}{l}\text { Fodder } \\
\text { yield }\end{array}$ & $\begin{array}{l}\text { Striga } \\
\text { resistance }\end{array}$ \\
\hline \multirow{2}{*}{ North } & Women & 87.0 & $90.7^{\star \star \star}$ & 33.8 & 8.8 & 20.4 & 19.8 & $19.0^{\star}$ & 3.1 & 9.4 & 4.8 & 3.4 \\
\hline & Men & 84.3 & $89.5^{\star \star \star}$ & 32.7 & 11.9 & 21.8 & 19.8 & $20.5^{\star \star}$ & 3.0 & 11.0 & 4.7 & 2.3 \\
\hline \multirow{2}{*}{ South } & Women & 90.4 & $53.7^{\star}$ & 36.8 & $37.9^{\star \star \star}$ & 13.0 & 34.1 & 5.6 & 6.0 & 8.6 & 5.7 & 1.1 \\
\hline & Men & 92.0 & 38.0 & 37.3 & $38.3^{\star \star \star}$ & 20.3 & $37.7^{\star}$ & 6.6 & $9.3^{*}$ & 10.5 & 9.8 & 0.9 \\
\hline
\end{tabular}

Asterisks indicate a significant different in selections rate between gender and region by chi-squared analysis,

${ }^{\star \star \star} p<0.001 ;{ }^{\star \star} p<0.01 ;{ }^{*} p<0.05$. 
82 and 15 years old, respectively. In Tiéfora department (south region), a total of 834 farmers participated in the 3-year study with a gender-balanced composition of $57.9 \%$ male to $42.1 \%$ female. The average age of participants was $36.0( \pm 1.8)$ years old, and the oldest and youngest participants were 80 and 14, respectively. From this analysis, the farmers surveyed in both regions covered a wide age range and were approximately gender balanced.

Table 2 shows the farmers' varietal selections made in each year. In the eight villages in the north region, the extra-early maturing white-seeded varieties IT98K-205-8 and IT99K-573-2-1 and early maturing genotype KVx442-2-25 were consistently selected as the preferred varieties. The brown-seeded KN1 and the late maturing variety IT81D-994 showed low popularity in the north. Although Melakh was the most popular variety in 2014, it fell out of the top three ranked varieties in 2015 and 2016. In contrast, the popularity of KVx396-4-5-2D suddenly increased in 2016.

In the five villages in the south region, farmers showed interest in a wide range of improved cowpea varieties, compared to the varieties selected in the north (Table 2). The early maturing genotype KVx442-3-25 was consistently selected across the study years. An extra-early maturing variety IT99K-573-2-1 and medium maturing genotype KVx775-33-2 showed steady popularity across the years. Although a late maturing variety with larger seed size, IT81D-994, fell into disfavour in 2015, it was a preferred variety in 2014 and 2016. Extra-early and early maturing varieties IT98K-205-8 and KVx771-10 showed significantly higher popularity in 2015 $(p<0.01)$ and medium maturing variety KVx396-4-5-2D showed significantly higher popularity in $2016(p<0.01)$. Melakh and KN1 showed significantly higher popularity in $2014(p<0.01$ and 0.001 , respectively), but fell into disfavour in 2015 and 2016.

\section{Farmers' selection criteria between the north and south regions of Burkina Faso}

Grain yield was an important selection criterion, with more than $85 \%$ of farmers in both particular regions identifying high grain yield as the key criterion for variety selection (Table 3 ). Significant differences in criteria between farmers in Tougouri department (north) and Tiéfora department (south) were found for maturity, plant type, seed colour, drought resistance and disease resistance. In the north, significantly more farmers $(90.1 \%)$ preferred early maturing genotypes than in the south $(45.9 \%)$. Plant type was a significantly more important criterion for farmers in the south $(38.1 \%)$ than for farmers in the north $(10.4 \%)$. In contrast, farmers in the north placed significantly more value on drought resistance (19.7\%) than did farmers in the south (6.1\%). Further, farmers in the south placed significantly higher importance on seed colour (35.9 vs. 19.8\%). Disease resistance had significantly higher importance in the south (7.6 vs. 3.0\%).

In both regions, there were several significant differences between men and women in the key criteria used to select cowpea varieties (Table 4). High grain yield was nominated as the most important criterion for selection in both regions. Preferences on the maturity, plant type, and drought resistance between men and women in each region were indicated similar trend with Table 3. Farmers' preferences in the south were slightly different between men and women, with early maturing cowpea being preferred by women than men, and men placing slightly more importance on seed colour and disease resistance than women.

The results of stepwise multiple regression reconfirmed that maturity (50\% flowering date) and seed colour were the most influential criteria for farmers' selection in the north, which is in contrast to seed size and seed colour as key criteria in the south (Table 5).

A large majority of farmers in the north preferred early maturing cowpea (96\%), as did farmers in the south (82.5\%). Further, farmers in the north preferred the prostrate plant type (92.3\%), while in the south, $67.2 \%$ of farmers preferred the erect plant type and $53.9 \%$ preferred the prostrate type (data not shown). Although a majority of farmers in both regions $(93.8 \%$ in the north and $70.6 \%$ in the south) indicated white as the preferred seed colour, $52.2 \%$ of farmers in the south also preferred red or dark brown. Clear differences between the two regions were observed in 
Table 5. Stepwise multiple regression between FPVS scores and measured variety field data

\begin{tabular}{|c|c|c|c|}
\hline \multicolumn{4}{|c|}{ Tougouri region (north) } \\
\hline Variable & Square sum & $F$ & $P$ \\
\hline $50 \%$ Flowering date & 774.18 & 5.63 & 0.025 \\
\hline Seed colour & 818.42 & 5.95 & 0.022 \\
\hline \multicolumn{4}{|c|}{ FPVS score (north) = $108.08-1.36$ ('date of 50\% flowering') - 17.63 ('seed color') } \\
\hline \multicolumn{4}{|c|}{ Tièfora region (south) } \\
\hline Variables & Square sum & $F$ & $P$ \\
\hline Seed size & 254.60 & 3.33 & 0.079 \\
\hline Seed colour & 183.37 & 2.40 & 0.133 \\
\hline \multicolumn{4}{|c|}{ FPVS score (south) $=18.96+1.29$ ('seed size') -8.80 ('seed color') } \\
\hline
\end{tabular}

farmers' preferences for seed size. The majority of farmers in the north (59\%) preferred medium seed size (15-20 g/100 seeds), while $37.2 \%$ preferred larger seeds ( $>20 \mathrm{~g} / 100$ seeds). In the south, $48.3 \%$ of farmers preferred larger seed size ( $>20 \mathrm{~g} / 100$ seeds) and $28.6 \%$ of farmers could accept medium seed size (15-20 g/100 seeds).

\section{Discussion}

Results from FPVS and the questionnaire survey indicated that high grain yield was the most universal trait used by farmers as a key criterion for variety selection in both Tougouri and Tiéfora departments of Burkina Faso. Among all criteria that influence variety selection, grain yield is the sole criterion that impacts agronomic performance, consumer preference and socioeconomic conditions (Dorp and Rulkens, 1993; Sperling et al., 1993). Based on yield data available for the highly preferred varieties, it is interesting to note that the most productive varieties are not necessarily the most popular varieties. Although there were no significant differences in yield between plots in Tougouri (north) and Tiéfora (south), the top three genotypes, including IT98K-205-8 in the north and IT99K-573-2-1 and IT81D-994 in the south, had lower productivity than other less frequently selected varieties (Table 2). Therefore, it was thought that farmers in these regions use second- and third-ranked criteria to make final decision. However, it is important to note that almost all varieties included in the demonstration plots were improved and/or recommended genotypes by IITA and INERA, and productivity may therefore be sufficiently high to satisfy farmers' preferences. Regional differences and preferences of farmers were thought to become clearly apparent in their selections, but to test this hypothesis, local varieties that farmers usually use should have been included in the selection and demonstration plots in order to compare productivity.

The identification of maturity as a significantly more important criterion for farmers in Tougouri department (north) than in Tiéfora department (south) may be due to lower rainfall in the north than in the south (Table 3), and thus the intense need for an early maturing cowpea. Early maturity is an alternative strategy to escape the adverse effects of drought for small-scale farmers. The higher market value of early maturing cowpea varieties compared with late maturing varieties (Bediako et al., 2009) makes them a good source of income, and it might be the reason why most farmers in the south who identified maturity as a selection criterion (45.9\%) preferred early maturing cowpea (82.5\%). Cowpea is mainly cultivated as an important cash crop by women in Burkina Faso (Baributsa et al., 2013). This may explain why women were slightly more sensitive to maturity as a selection criterion than men in Tiéfora department (Table 4). However, the early maturing trait is often achieved in a trade-off with seed size, causing farmers to tend to select medium to late maturing genotypes in years when rainfall is sufficient (Supplementary Material Table S1). 
Rainfall could be a factor that influence farmers' selection criteria. In the north, seed size is genetically predetermined, however, it could not increase in growing periods with limited rainfall. In such situations, late maturing cowpea varieties with large seed size could not reach maturity and/or would show a loss in productivity due to the short rainy season. Consumers value large seed size in cowpea markets in Cameroon, northern Ghana, Nigeria and Senegal and pay a premium for white cowpea with black eyes in Ghana (Langyintuo et al., 2003). However, for seed size, the trade-off between grain yield and maturity must be considered. Therefore, farmers in Tougouri department (north) preferred large seed size cowpea varieties that also optimised productivity for their growing conditions due to early maturity. Farmers in Tiéfora department (south) preferred large seed size cowpea varieties, which optimised market value due to large seed size. In addition, farmers should be sensitive to plant type due to high humidity and flood damage potential for cowpea in high-rainfall areas. Therefore, it was thought that farmers in Tiéfora (south) place higher importance on plant type and preferred erect type plants to avoid flood damage. Further, disease resistance may have had higher importance in Tiéfora (south) than in Tougouri (north) due to the causative relationship between high humidity and disease. Conversely, farmers in the north consider that drought resistance was a more important criterion than in the south, and they placed less importance on plant type.

Another challenge to successful cultivation of cowpea is lessening or avoiding infestation with S. gesnerioides, a parasitic weed of agricultural crops in Africa that causes significant losses in crop yield. Although S. gesnerioides was present in all demonstration fields used for the FPVS in both regions, a certain level of emerged and infection was observed on susceptible varieties in the north but not in the south, although the rate of emerged was not high. Therefore, the effect of S. gesnerioides on variety selection was not discussed.

Regional differences in the use of a crop impact the selection criteria. An on-station farmer evaluation of cowpea breeding lines in Cameroon by Kitch et al. (1998) showed that fodder yield along with grain yield were also important traits. Herein, farmers' preference for fodder yield was not considered to be a key selection criterion in the targeted area. Generally, farmers in West Africa utilise cowpea fodder as feed for livestock, especially during the dry season, and/or as a commodity for sale in the market to generate additional income. Although farmers in these areas of Burkina Faso do use cowpea as fodder for animal feed, they use cowpea leaves as food for human consumption (data not shown). Thus, the obtained result suggests that preference for the fodder yield may differ by region and/or country.

Seed colour was important in Tiéfora area (south), a specific preference of farmers and that of the markets based on local culture. High farmer preference for specific seed colour reflecting local market demands has been reported in Cameroon (Kitch et al., 1998) and northern Nigeria (Kamara et al., 2009). The south of Burkina Faso is linked to markets of Mali and Cote d'Ivoire through Bobo-Dioulasso. Therefore, farmers in Tiéfora department would find it advantageous to select various coloured cowpea varieties matched to market preferences and local culture, provided the other traits met their requirements. On the other hand, farmers in Tougouri area (north) showed low acceptance for brown and black seeds (Table 2).

Furthermore, Mishili et al. (2006) reported that efforts to improve the cowpea market in West Africa should target cowpea grain size and its storage technology (to reduce the grain damage). Specific traits revealed by statistical methods could contribute to the identification of key traits for enhancement of the cowpea value chain. Farmers who participated in FPVS trials were categorised into three groups based on their major production activity: (i) mainly sale as a crop; (ii) use for home consumption; and (iii) use as both a cash and food crops (data not shown). On average, $10.8 \%$ of farmers use cowpea for home consumption, $2.4 \%$ for cash crop (sale), and $85.9 \%$ of farmers use cowpea for home consumption + cash crop in the north. In the south, about $33.9 \%$ farmers use cowpea for home consumption, $0.3 \%$ for cash crop (sale), and $63.2 \%$ for home consumption + cash crop (data not shown). Therefore, it seems that participants are producers and consumers at the same time. Although our research focussed on farmers' preferences to 
determine acceptable traits, if farmers' (and/or consumers') preferences reflect actual cowpea purchases, our data might also be useful for pricing studies.

\section{Conclusion}

Capturing the demands of the surrounding local markets and connected regional markets is necessary to improve adoption of the selected varieties in the target region. Data from FPVS and questionnaire survey could provide important suggestions for the further development of cowpea breeding strategies targeting the north and south regions of Burkina Faso. If the demonstrated varieties have sufficient yield performance, the final selection of the variety was determined by the second and third selection criteria of farmers in the region. In Tougouri department (north), early maturing and white seeded cowpea take precedence over other criteria. In Tiéfora department (south), large seed cowpea and colour preferences, which depend on region, take precedence. These differences in selection criteria depend on regional and local factors, and there is little or no difference between selections made by men and women. Since significant differences among the regions regarding preferences for these criteria were suggested, a better understanding of regional preferences with regard to traits is the key for the selection of suitable varieties for target regions. Therefore, in order to determine the improved variety and/or to achieve better acceptance of an improved variety, regional preferences should be gathered and analysed before release of the variety. Applying the formula of 'grain yield $+2^{\text {nd }}$ (or $3^{\text {rd }}$ ) key criterion = regional preferences' will better inform recommendations for cowpea varieties for different regions. In addition, the results of this study showed that breeding strategies should address region-specific preferences in order to improve the acceptance of improved cowpea varieties.

Author ORCIDs. (D) Haruki Ishikawa 0000-0001-6215-2622

Acknowledgements. This work was conducted as part of international collaborative research projects funded by the Japanese Ministry of Agriculture, Forestry and Fisheries.

\section{References}

Ashby J.A. and Lilja N. (2005). Participatory research: does it work? Evidence from participatory plant breeding. In Proceedings of $4^{\text {th }}$ International Crop Science Congress, 'New Directions for a Diverse Planet', 26 September-1 October, Brisbane, Australia.

Baributsa D., Dabiré C., Sawadogo K. and Lowenberg-DeBoer J. (2013). Increasing women's participation in cowpea storage activities: The case of Burkina Faso. Journal of Agricultural Extension and Rural Development 5, 232-239.

Bediako J., Chianu J. and Dodson J. (2009). Crop storage efficiency and market competitiveness: Case of groundnut and cowpea in Ghana. African Journal of Marketing Management 1, 81-88.

Dorp M. and Rulkens T. (1993). Farmer crop-selection criteria and genebank collections in Indonesia. In W. de Boef, K. Amonor, K. Wellard and A. Bebbington (eds), Cultivating Knowledge. Genetic Diversity, Farmer Experimentation and Crop Research. ( W. de Boef, K. Amonor, K. Wellard and A. Bebbington) London: Intermediate Technology Publications Ltd., pp. 119-127.

FAOSTAT (2014). http://www.fao.org/faostat/.

Faye M., Jooste A., Lowenberg-DeBoer J. and Fulton, J. (2006) The influence of cowpea characteristics on cowpea prices in Senegal. Agrekon 43, 418-429.

Kamara A.Y., Ellis-Jones J., Ekeleme F., Omoigui L., Amaza P., Chikoye D. and Dugje I.Y. (2009). A participatory evaluation of improved cowpea cultivars in the Guinea and Sudan savanna zones of north east Nigeria. Archives of Agronomy and Soil Science 56, 355-370.

Kitch L.W., Boukar O., Endondo C. and Murdock L.L. (1998). Farmer acceptability criteria in breeding cowpea. Experimental Agriculture 34, 475-486.

Kormawa P.M., Chianu J.N. and Manyong V.M. (2002). Cowpea demand and supply patterns in West Africa: the case of Nigeria. In C.A. Fatokun, S.A. Tarawali, B.B. Singh, P.M. Kormawa and M. Tamo (eds) Challenges and Opportunities for Enhancing Sustainable Cowpea Production, 376. M. TamoNigeria: International Institute of Tropical Agriculture. 
Langyintuo A.G., Ntoukam L., Lowenberg-DeBoer J. and Miller D.J. (2004) Consumer Preference for Cowpea in Cameroon and Ghana. Agricultural Economics 30, 203-213.

Langyintuo A.S., Lowenberg-DeBoer J.F., Lambert D., Ibro G., Maussa B., Kergna A., Kushuwaha S., Musa S. and Ntoukam G. (2003). Cowpea supply and demand in West and Central Africa. Field Crops Research 82, 215-223.

Lowenberg-DeBoer J. (1994). Preliminary Impact Assessment study for CRSP cowpea technologies in Cameroon: Purdue/IRA cowpea storage project. East Lansing, Michigan: Michigan State University, Bean/Cowpea collaborative research support program (CRSP). Trip Report, 11-30 October, 5-9 November, 1994, Ghana, Cameroon and Mali.

Mishili F.J., Fulton J., Shehu M., Kushwaha S., Marfo K., Jamal M., Chergna A. and Lowenberg-DeBoer J. (2007), Consumer preferences for quality characteristics along the cowpea value chain in Nigeria, Ghana, and Mali, Working Paper \#06-17, Purdue University, College of Agriculture, Department of Agricultural Economics.

Mortimore M.J., Singh B.B., Harris F. and Blade S.F. (1997). Cowpea in traditional cropping systems. In B.Singh B., D.Mohan Raj R., K.Dashiell E. and L.E.Jackai N. (eds) Advances in Cowpea Research, 99 Singh B. B., Mohan Raj D. R., Dashiell K. E. and Jackai L. E. N.. Nigeria: Co-publication of International Institute of Tropical Agriculture (IIA) and Japan International Research Center for Agricultural Sciences (JIRCAS).

Muranaka S., Shono M., Manjula K., Takagi H. and Ishikawa H. (2015). Application of near to mid-infrared spectroscopy to estimation of grain nitrogen content in cowpea (Vigna Unguiculata) grown under multiple environmental conditions. Journal of Biological and Food Science Research 4: 16.

Sanders J., Bezuneh T. and Schroeder A. (1994). Impact Assessment of the SAFGRAD Commodity Networks. Washington, DC: USAID/AFR/ARTS/FARA.

Sperling L., Loevinsohn M.E. and Ntabomvura B. (1993). Rethinking the famer's role in plant breeding: local bean experts and on-station selection in Rwanda. Experimental Agriculture 29, 509-519.

Witcombe J.R., Joshi A., Joshi K.D. and Sthapit B.R. (1996). Farmer participatory crop improvement. I. Varietal selection and breeding methods and their impact on biodiversity. Experimental Agriculture 32, 445-460.

Cite this article: Ishikawa H, Drabo I, Joseph BB, Muranaka S, Fatokun C, and Boukar O (2020). Characteristics of farmers' selection criteria for cowpea (Vigna unguiculata) varieties differ between north and south regions of Burkina Faso. Experimental Agriculture 56, 94-103. https://doi.org/10.1017/S001447971900019X 